\title{
Physicochemical properties of dacquoise made with sugar or sugar replacements, tagatose, and erythritol
}

\author{
Na Ra Lee ${ }^{1}$ Suna Kang' Ji Hyun Kim² $\cdot$ Ha Hyoung Kim² Jung Ah Lee $^{2}$ \\ - Sunmin Park ${ }^{1,2}$
}

\section{타가토스와 에리스리톨로 제조한 다쿠아즈의 물리화학적 특성 연구}

이나라 ${ }^{1}$ - 강선아 ${ }^{2}$ - 김지현 ${ }^{2}$ - 김하형 ${ }^{2}$ 이정아 ${ }^{2}$ - 박선 민 ${ }^{1,2}$

Received: 7 January 2017 / Accepted: 31 January 2017 / Published Online: 31 March 2017

(C) The Korean Society for Applied Biological Chemistry 2017

\begin{abstract}
The objective of this study was to investigate the physicochemical characteristics and sensory evaluation of dacquoise made with sugar or sugar replacement (tagatose, erythritol). Sugar (S) was replaced with tagatose (T), and sugar powder was replaced with tagatose (TS), and erythritol (TE). S showed the highest sugar contents compared with TS and TE $(p<0.05)$ but there were no significant differences with $\mathrm{T}$. There were not significant differences in specific gravity and spread factor among the sweeteners. S and T tended to have higher loss factors than TS \& TE. The more tagatose was increased, the more the redness value increased compared with $\mathrm{S}$, and sucrose showed similar tendency for lightness (redness; TS $>\mathrm{T}>\mathrm{TE}>\mathrm{S}$, lightness; $\mathrm{S}>\mathrm{T}>\mathrm{TS}>$ TE). TE showed good results for physical characteristics whereas $\mathrm{T}$ was better in the sensory test. The above results bear out that tagatose and erythritol both are suitable as alternative sweeteners for making dacquoise, but tagatose was better. Tagatose appeared to be a better replacement for sucrose in baking dacquoise, and
\end{abstract}

$\mathrm{Na}$ Ra Lee and Suna Kang contributed equally.

Sunmin Park $(\triangle)$

E-mail: smpark@hoseo.edu

${ }^{1}$ Department of Nanobiotronics, Hoseo University, Asan 31499, Republic of Korea

${ }^{2}$ Department of Food and Nutrition, Institute of Basic Science, Hoseo University, Asan 31499, Republic of Korea

This is an Open Access article distributed under the terms of the Creative Commons Attribution Non-Commercial License (http://creativecommons. org/licenses/by-nc/3.0/) which permits unrestricted non-commercial use, distribution, and reproduction in any medium, provided the original work is properly cited. dacquoise with $33 \%$ of the sugar replaced tagatose (T) could be suitable for use by diabetic and obese people. 95.1\% tagatose (TS) maybe appropriate for diabetic patients. In conclusion, tagatose is a suitable sugar replacement for making dacquoise.

Keywords Alternative sweetener - Dacquoise - Erythritol · Sucrose $\cdot$ Tagatose

\section{서 론}

근래에 들어 우리나라는 식품의 산업화로 많은 변화를 겪고 있 다. 서구화된 식단, 외식의 증가 등으로 식생활이 변화되면서 비만, 당뇨병과 같은 성인병의 발병률이 점점 증가되고 있으며 (Kim 등, 2015) 그 중 당뇨병은 한국인의 10 대 사망원인 중 한 가지로 꼽히고 있다(Lee와 Song 2016). 아시아인들에서 특히 급 증하고 있는 제 2형 당뇨병은 인슐린 저항성이 증가할 때 인슐 린 분비 장애로 인해 나타나는 질환으로, 노화나 염증, 체중증 가 등으로 인슐린 저항성이 증가로 인해 발병된다(Son 등, 2011). 당뇨병 환자나 대사성 증후군을 가진 사람들은 급격한 혈당 변화로 인해 합병증에 노출되기 쉽다. 설탕을 다량 함유 하고 있는 식품은 당지수(glycemic index)가 높은 식품으로 혈 당을 높이고, 비만, 이상지혈증을 유도하는 단점을 가지고 있다. 가공식품 제조 시 단맛을 내기 위해 설탕을 주로 사용하고 있 으나, 다양한 성인병의 원인으로 설탕이 지목되면서 이를 대체 할 수 있는 대체감미료에 대한 요구가 증가하고 있다 $(\mathrm{Kim}$ 과 Lee 2016). 설탕은 $4 \mathrm{kcal} / \mathrm{g}$ 의 열량을 내며, 체내 흡수가 빨라 당뇨병, 비만과 같은 성인병에 원인물질로 알려져 있고(Lee와 Woo 2001), 과다 섭취 시 비만이 유도될 수 있으며(Ludwig 등, 
2001), 주의력 결핍 과잉 행동 증후군(Attention Deficit Hyperactivity Disorder; $\mathrm{ADHD}$ ) 아동이 정상 아동에 비하여 설탕섭취 량이 유의적으로 높다(Chung과 Park 1995)는 보고도 있다.

천연감미료 중 하나인 타가토스(tagatose)는 $1 \mathrm{~g}$ 당 $1.5 \mathrm{kcal}$ 의 열량을 내며, 설탕의 0.92 배의 감미도를 가진다. 타가토스는 과 일, 우유 등에 존재하는 천연감미료라는 장점을 가지며, 체내에 서 거의 대사되지 않고, 과량을 섭취해도 설사를 유발하지 않 으며(Roh 등, 1999), 혈당 강하 효과가 있는 것으로 알려져 있 다(Donner 등, 1996; Kang과 Lee 2016). 타가토스는 한국식품 의약품안전처(KFDA), 미국식품의약국(FDA, GRAS) (Levin 2002), 유럽식품안전국(EFSA)에 높은 품질의 재료로 지정되어 있다. 타가토스의 당지수는 3으로, 당지수가 68인 설탕이나 24 인 과당에 비해 매우 낮고, Chiu 등(2011)은 타가토스를 섭취 한 당뇨병 환자의 혈당이 낮아졌다고 보고하였다.

당 알코올 유래 천연감미료 중 에리스리톨(erythritol)은 $1 \mathrm{~g}$ 당 $0.2 \mathrm{kcal}$ 로 열량이 거의 없고, 설탕의 약 0.75 배의 감미도를 가진다. 에리스리톨은 당지수가 1 로 매우 낮으며, 혈당과 인슐 린 수치 증가나 혈중 지질에 영향을 미치지 않는 것으로 알려 져 있으나(Noda 등, 1994), $50 \mathrm{~g}$ 이상으로 과다하게 섭취할 경 우 삼투압으로 인해 설사를 하거나 메스꺼울 수 있다는 보고도 있어 한번에 일정량 이상을 섭취하지 않도록 조절해야 한다 (Storey 등, 2007).

다쿠아즈는 팽창제나 이스트를 사용하지 않고 머랭을 이용한 팽창력에 의존하는 디저트로, 아몬드나 헤이즐넛, 휘핑크림 등 을 층으로 제작하여 만든 디저트 케익도 다쿠아즈의 일종이다 (Child와 Simone 1978). 다쿠아즈를 제조하는 반죽은 케이크를 제조할 때의 반죽과 유사하다. 일반적으로 제과, 제빵에서는 설 탕을 주재료로 사용하므로 대사성증후군을 가진 사람들이나 당 뇨병 환자들에게는 섭취를 제한할 수 밖에 없다.

본 연구의 목적은 설탕을 천연감미료로 대체하여 당에 대한 부담감을 줄임으로써, 대사성 증후군이나 당뇨병을 가진 환자들 이 섭취할 수 있는 당지수를 낮춘 다쿠아즈를 제조하는 것이다. 또한, 대체 감미료로 제조한 다쿠아즈의 물리적 특성 및 관능 검사를 통하여 고품질의 당지수가 낮은 다쿠아즈를 개발하고자 하였다.

\section{재료 및 방법}

\section{재료}

본 다쿠아즈 제조 실험해서 사용된 재료는 타가토스(CJ, Incheon, Korea), 에리스리톨(Mitsubishi Kagaku Foods, Tokyo, Japan), 박력분 밀가루(Kyouwon, Chungnam, Korea), 설탕 (Kyouwon, Ulsan, korea), 달걀, 아몬드분말(Jilimyanghang, Gyeonggi, Korea), 분당(sugar powder, Kyouwon, Ulsan, Korea), 전분(Seongjin Food, Chungnam, Korea), 바닐라 향 (Jeonwonfood, Gyeonggi, Korea)으로, 시중에 판매되는 제품을 구매하여 다쿠아즈를 제조하는데 사용하였다.

\section{군 분류 및 제조방법}

대체 감미료를 사용하여 제조한 다쿠아즈의 조성은 Table1에 나 타내었다. 대조군은 설탕 $(\mathrm{S})$ 으로 정하였고, 실험군 1 은 타가토
Table 1 Ingredients and mix proportioning of dacquoise (unit: g)

\begin{tabular}{ccccc}
\hline Ingredient & $\mathrm{S}$ & $\mathrm{T}$ & $\mathrm{TS}$ & $\mathrm{TE}$ \\
\hline Egg white & 35 & 35 & 35 & 35 \\
$\quad$ Sugar & 17 & & & \\
Tagatose & & 17 & 17 & 8.5 \\
Erythritol & & & & 8.5 \\
Almond powder & 34 & 34 & 34 & 34 \\
& & & Tagatose 31.5 & Tagatose 15.75 \\
& & 34 & Starch 2.5 & Erythritol 15.75 \\
Sugar powder & 34 & & 6 & Starch 2.5 \\
& & & 0.5 & 0.5 \\
Soft flour & 6 & 6 & 126.5 & 126.5 \\
Vanilla oil & 0.5 & 0.5 & & \\
Total & 126.5 & 126.5 & &
\end{tabular}

S: Dacquoise with sugar and sugar powder

T: Dacquoise with tagatose and sugar powder

TS: Dacquoise with tagatose and sugar powder replacement (tagatose and starch)

TE: Dacquoise with tagatose and sugar powder replacement (tagatose, erythritol and starch)

스(T), 실험군 2는 타가토스+전분(TS), 실험군 3은 타가토스+ 에리스리톨+전분(TE)으로 정하였다. 다쿠아즈의 배합비는 예비 실험에서 다쿠아즈의 최적 배합비율을 탐색하였고, 탐색한 비율 로 다쿠아즈를 제조하여 실험에 사용하였다. 바닐라향은 다쿠아 즈의 기호도를 높이기 위해 첨가하였다.

계란을 흰자와 노른자로 분리한 후, 거품기를 이용하여 머랭 치기를 하였고, 흰자 거품이 거품기에 붙을 때까지 해주었다. 설탕, 대체감미료(타가토스, 에리스리톨)를 2 3번으로 나누어 거 품을 낼 때 섞어주었다. 박력분, 전분, 분당, 바닐라향을 체에 쳐서 볼에 넣어 나무주걱으로 섞어준 후, 실험에 사용할 반죽 을 제외하고, 짤 주머니에 넣어 유산지를 놓은 오븐 팬 위에 3 $\mathrm{cm}$ 동그란 크기로 $6 \mathrm{~g}$ 씩 짜고 팬닝을 한 후, $180{ }^{\circ} \mathrm{C}$ 로 예열한 오븐에 13 15분 정도 구웠다. 굽는 시간은 예비실험을 통해 갈 변이 적게 나타나는 적정 시간을 탐색하여 정하였다.

구워진 다쿠아즈는 팬에서 분리하여 식힘 망에서 한 시간 식 힌 후 바로 실험에 사용하였다. 다쿠아즈 반죽으로는 당도, 비 중을 측정하였고, 구운 후 다쿠아즈로는 색도와 조직감을 측정 하였다. 퍼짐성의 경우 굽기 전의 다쿠아즈 반죽과 구운 후의 다쿠아즈의 직경과 두께의 차이로 나타내었고, 손실률의 경우 굽기 전 다쿠아즈 반죽의 무게와 구운 후의 다쿠아즈의 무게를 측정하여 나타내었다.

\section{당도(Sweetness)}

대체 감미료에 따른 다쿠아즈의 단맛을 알아보기 위해 당도를 측정하였다. 당도 측정은 굽기 전, 제조한 반죽을 물을 섞어 10 배로 희석한 후, 당도계(ATAGO N-50E, Osaka, Japan)를 사용 하여 3회 반복 측정하여 평균값으로 나타내었다.

\section{비중(Specific gravity)}

대체 감미료에 따른 다쿠아즈의 비중의 변화를 알아보고자 다 쿠아즈를 굽기 전 반죽을 물에 넣어 다쿠아즈의 비중을 측정하 였다. 비중 컵에 물을 넣어 물의 무게를 측정하고, 다쿠아즈 반 죽을 컵에 채워 반죽의 무게를 측정한 뒤 3 회 반복하여 비중 
값으로 사용하였다(AACC 1983). 비중 측정 계산식은 아래와 같다.

비중(\%) (Specific gravity)=반죽의 무게/물의 무게

\section{퍼짐성(Spreadability)}

다쿠아즈의 퍼짐성은 제조한 다쿠아즈의 굽기 전과 구운 후의 직경과 두께의 차이로 나타내었다. 굽기 전 다쿠아즈의 직경과 두께를 측정하고, 구운 후 다쿠아즈의 직경과 두께를 계산하는 AACC (1985) method 10-50D 방법을 사용하여 퍼짐성을 나타 내었다. 3 회 반복 측정하여 평균값으로 나타내었으며 계산식은 아래와 같다.

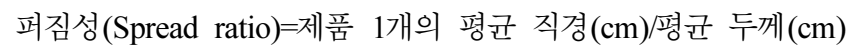

\section{손실률(Loss factor)}

다쿠아즈의 손실률을 측정하기 위해 굽기 전 다쿠아즈의 반죽 무게와 구운 후의 다쿠아즈의 무게를 측정하여 손실률을 계산 하였다. 3 회 반복 측정하여 평균값으로 나타내었고, 손실률 계 산방법은 아래와 같다.

$$
\text { 손실률 }(\%)=\{(\mathrm{A}-\mathrm{B}) / \mathrm{A}\} \times 100
$$

$\mathrm{A}=$ 굽기 전 반죽의 무게 $(\mathrm{g})$

$\mathrm{B}=$ 구운 후 다쿠아즈의 무게 $(\mathrm{g})$

\section{색도(Chromaticity)}

다쿠아즈의 색도를 측정하기 위해 구운 후의 다쿠아즈를 색도 계(Color spectrophotometer, CM-3500d, Minolta Co Ltd., Osaka, Japan)를 사용하여 L값(명도)은 0(black)에서 100(white) 까지, $\mathrm{a}$ 값(적색도)은 -80 (green)에서 100 (red)까지, $\mathrm{b}$ 값(황색도) 는 -70 (blue)에서 70 (yellow)까지의 범위 값을 나타낸다. 각각의 샘플은 3 회 반복 측정하여 평균값으로 나타내었다.

\section{조직감(Texture)}

다쿠아즈의 조직감을 측정하기 위해 구운 후의 다쿠아즈를 texture analyzer(TA-XT Express, Texture Technologies Co., Ltd., Godalming, England)를 사용하여 경도(Hardness), 부서짐 성(Fracturability), 점착성(Adhesiveness), 탄력성(Springness), 응 집성(Cohesiveness)을 3회 반복 측정하여 평균값으로 나타내었다.

\section{관능평가(Sensory evaluation)}

구운 다쿠아즈를 호서대학교 학생들에게 공지하고 자발적으로 참여한 15 명을 대상으로 관능평가 방법을 교육한 후 관능평가 를 실시하였다. 5점 척도로 15 명의 평균값을 나타내었으며, 색 (color), 향(flavor), 맛(taste), 질감(texture), 전체적 기호도(overall acceptance)의 5 가지 항목으로 구성된 관능평가표를 이용하여 실 시하였으며, 각 항목에 대해 1점에서 5 점까지의 점수를 기입하 는 방식으로 설문조사를 하였다(5점: 매우 좋다, 4점: 좋다, 3점: 보통이다, 2점: 싫다, 1점: 매우 싫다).

\section{통계처리(Statistics process)}

실험결과는 통계처리 하여 평균 \pm 표준편차로 측정하였고, SPSS program (SPSS Inc., Chicago, IL, USA)을 이용하여 대체감미
료를 달리한 다쿠아즈의 다양한 특성에 대한 통계적 유의성을 one-way ANOVA로 측정하였다. 군들 사이에 통계적 유의성이 있는 것은 Tukey test로 검정하였고, 통계적으로 유의한 경우 $p<0.05$ 로 나타내었다.

\section{결과 및 고찰}

\section{당도}

당도 측정결과는 Fig. $1 \mathrm{~A}$ 에 나타내었다. 대조군(설탕, $\mathrm{S}$ ), 실험 군 1(타가토스, T), 실험군 2(타가토스+전분, TS), 실험군 3(타 가토스 + 에리스리톨 $+($ 타가토스 + 에리스리톨 + 전분, TE)) 순으로 당도가 높게 나타났다. TS가 S보다 약 0.2(brix) 정도 낮게 나 왔으나, 유의적인 차이는 없었다. 다쿠아즈 제조 시 첨가되는 설탕 및 분당(powdered sugar)과 대체감미료가 당도 결과에 영 향을 주었다. $\mathrm{T}, \mathrm{TS}, \mathrm{TE}$ 순으로, 설탕 첨가량이 감소함에 따라 당도 값도 감소하는 경향을 보였다. Lee 등(2008)은 알코올 유 래당인 자일리톨과 설탕을 $1: 1$ 로 첨가하여 제조한 식빵과 설탕 만으로 제조한 식빵과 유사한 당도를 나타내었고, 자일리톨 만 으로 제조한 식빵은 낮은 당도를 나타냈다고 보고하였다.

Fujimaru 등(2012)은 감미료는 농도에 따라 단맛이 증가하는 경향은 달랐으나, $5 \%$ 의 설탕물과 비교 하였을 때 타가토스는 $5.6 \%$, 에리스리톨 $8.7 \%$ 의 농도일 때 설탕과 같은 농도를 나 타냈다고 보고하였다. 설탕의 비율이 높았던 $\mathrm{S}$ 와 $\mathrm{T}$ 의 당도 값 이 유사하게 높은 값을 나타내었고, TS, TE는 유의적으로 낮은 값을 나타내었는데, 이는 타가토스와 에리스리톨이 가지는 구조 적인 차이로 인한 결과로 사료된다. 당도계는 재료를 물에 녹 여, 물에 녹은 물질(무기질, 설탕, 아미노산, 수용성 물질 등)이 굴절시켜 용매 내 존재하는 물질의 량을 brix 단위로 나타내는 원리로 해석되는데, 2 분자 화합물인 설탕 $(\mathrm{M} . W: 342.3 \mathrm{~g})$ 과 1 분 자 화합물인 타가토스 $(180.2 \mathrm{~g})$ 와 에리스리톨 $(122.1 \mathrm{~g})$ 간의 크 기 차이로 인해 위와 같은 결과가 나온 것으로 보인다.

\section{비중}

비중 결과는 Fig. $1 \mathrm{~B}$ 에 나타내었다. (반죽의 무게/물의 무게)으 로 측정하였고, 다쿠아즈 각각의 비중을 측정 결과 $\mathrm{TE}>\mathrm{TS}>$ $\mathrm{T}>\mathrm{S}$ 순으로 나타났다. $\mathrm{TE}$ 가 다른 군에 비해 수치가 제일 높 게 나왔으나 군들 간의 유의적인 차이는 없었다. 반죽의 비중 은 케익이나 베이커리 제품의 부피와 관련이 있는데 (Lakshminarayan 등, 2006), 비중이 높으면 다쿠아즈의 부피가 줄어들게 된다. 비중 값이 다르게 나타나는 것은 만들어진 제 품의 품질이 다르게 변하는 것을 의미하지만, 실험결과 비중에 서 큰 차이를 보이지 않았다. 결과적으로 0.01 정도의 미미한 차이로 대체감미료는 비중에 큰 영항을 끼치지 않았다.

\section{퍼짐성}

퍼짐성은 굽기 전과 구운 후의 다쿠아즈의 직경 $(\mathrm{cm})$ 을 두께 $(\mathrm{cm})$ 로 나누어 측정하여 나타낸 것으로 Fig. $2 \mathrm{~A}$ 에 나타내었다. 퍼 짐성 측정 결과 $\mathrm{TE}>\mathrm{TS}>\mathrm{T}>\mathrm{S}$ 순으로 나타났으나 유의적인 차 이는 없었다.

Pasha 등(2002)은 대체감미료를 사용한 쿠키의 품질에 대하 여 연구하였는데, 설탕과 fructose를 $1: 1$ 로 넣은 쿠키의 spread 

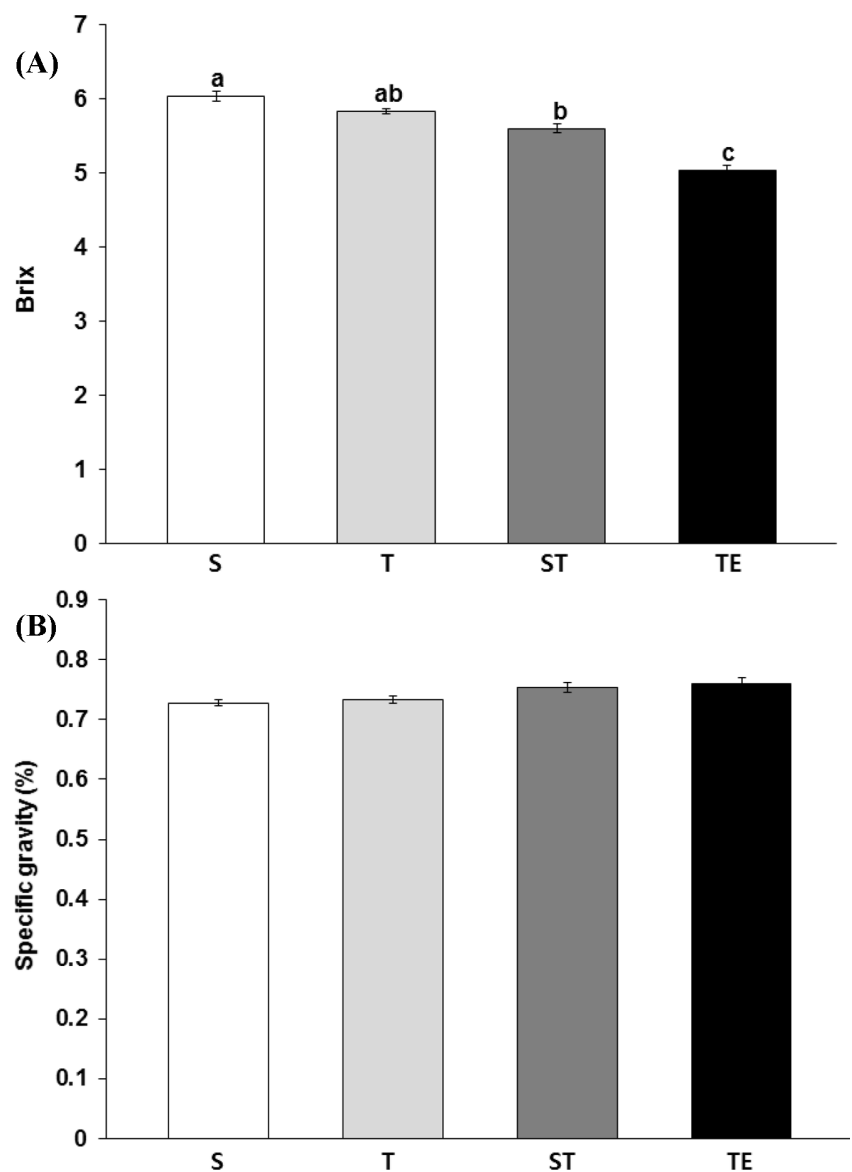

Fig. 1 Sweetness (A) and specific gravity (B) of dacquoise made of alternative sweetener

S: Dacquoise with sugar and sugar powder

T: Dacquoise with tagatose and sugar powder

TS: Dacquoise with tagatose and sugar powder replacement (tagatose and starch)

TE: Dacquoise with tagatose and sugar powder replacement (tagatose, erythritol and starch)

a,b,cBars with different superscripts were significantly different by Tukey's test at $p<0.05$

factor가 40.8, 설탕이 36.8 , fructose가 $34.6 \mathrm{~cm}$ 를 나타내었고, polyols 류(sorbitol, mannitol)의 spread factor 값은 32.1 이하 로 낮게 나타났다고 보고하였다. Pareyt 등(2009)은 설탕의 첨 가량을 달리 제조하였을 때, 쿠키 반죽의 점도와 쿠키의 구조 에 영향을 미쳤는데 특히 쿠키의 높이와 쿠키에 생기는 균열에 영향을 미친다고 보고하였다. Akesowan (2009)은 대체감미료의 량이 증가할수록 케익의 부피가 감소하고, 무게와 수분활성도는 증가하였다고 보고하였다. Ronda 등(2005)은 polyols계의 대체 감미료를 첨가한 케익이 설탕으로 제조한 것에 비하여 낮은 부 피를 나타냈다고 보고하였다. 본 실험에서는 대체감미료에 따라 퍼짐성이 달라지는 모습을 보이기는 하였으나 유의적인 차이는 없었고, Pasha 등(2002)과 Ronda 등(2005)의 결과와 달리 TE 의 퍼짐성 지수가 가장 높았으나, 유의적인 차이를 보이지는 않 았다.
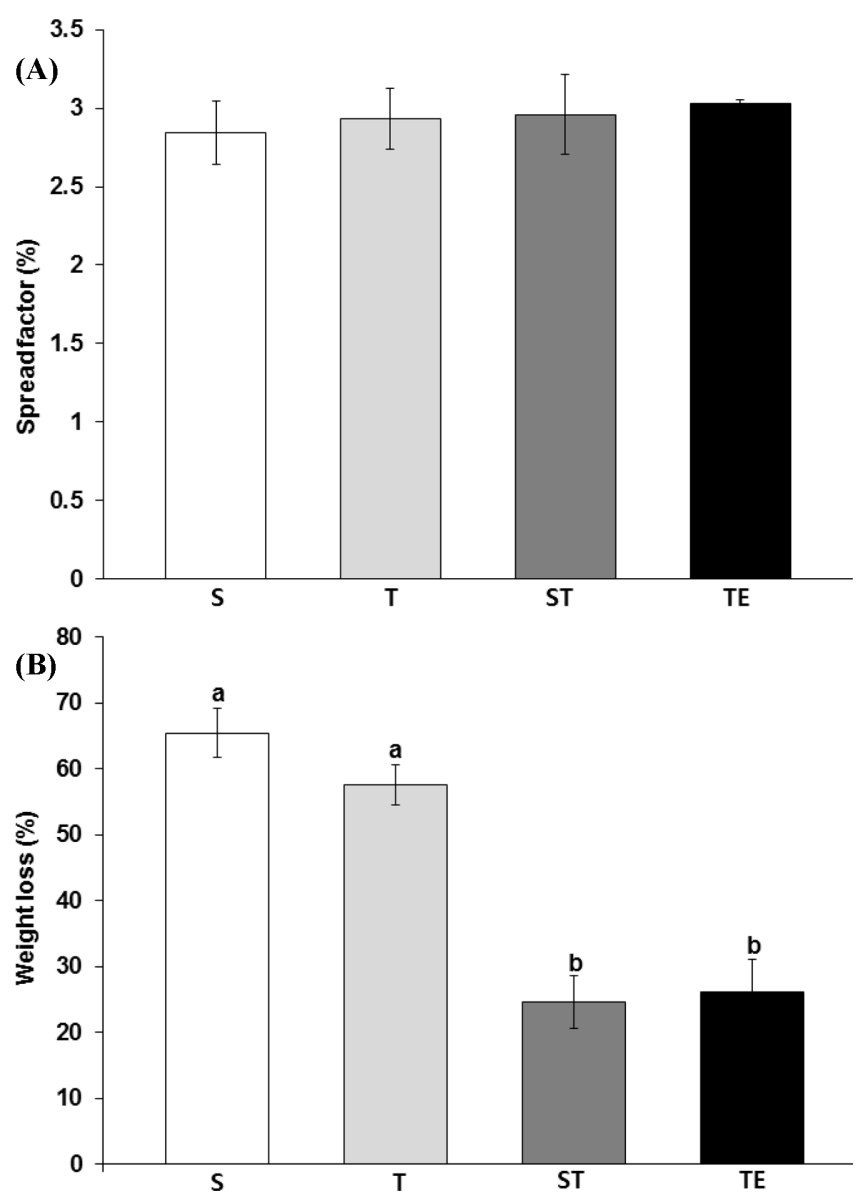

Fig. 2 The spread factor (A) and water loss (B) of dacquoise made of difference sweetener

S: Dacquoise with sugar and sugar powder

T: Dacquoise with tagatose and sugar powder

TS: Dacquoise with tagatose and sugar powder replacement (tagatose and starch)

TE: Dacquoise with tagatose and sugar powder replacement (tagatose, erythritol and starch)

a,b Bars with different superscripts were significantly different by Tukey's test at $p<0.05$

\section{손실률(loss factor)}

손실률은 구운 후의 다쿠아즈를 굽기 전의 반죽으로 나눈 후 백분율로 나타내었으며, 결과는 Fig. 2B에 나타내었다. 손실률 의 수치는 $\mathrm{S}>\mathrm{T}>\mathrm{TS}>\mathrm{TE}$ 순으로 설탕으로 제조한 다쿠아즈의 손실률이 가장 컸다. $\mathrm{S}$ 와 $\mathrm{T}$ 간에 유의적인 차이는 없었으나 $\mathrm{S}$ 보 다 $\mathrm{T}$ 의 손실률이 더 낮았고 $\mathrm{TE}, \mathrm{TS}$ 순으로 낮은 손실률을 보 였다. 설탕을 타가토스로 대체한 $\mathrm{T}$ 가 $\mathrm{S}$ 보다 손실률이 낮았고, 분당을 타가토스로 대체한 TS군과 에리스리톨과 타가토스를 함 께 첨가한 $\mathrm{TE}$ 군이 $\mathrm{T}$ 보다 낮은 손실률을 보였다. Hwang (2014) 등은 타가토스의 첨가량에 따른 머핀의 품질에 대해 연 구하였는데 타가토스의 첨가량이 증가할수록 손실률이 감소하 였다고 보고하였다. 본 실험결과 Hwang (2014) 등의 결과와 유 사하게 타가토스의 첨가량이 증가할수록 다쿠아즈의 손실률이 적은 경향을 보였다. 결과적으로 분당을 타가토스나 에리스리톨 
Table 2 Chromaticity of dacquoise made of alternative sweetener

\begin{tabular}{ccccc}
\hline & $\mathrm{S}$ & $\mathrm{T}$ & $\mathrm{TS}$ & $\mathrm{TE}$ \\
\hline $\mathrm{L}$ & $30.2 \pm 0.2^{\mathrm{a}}$ & $25.1 \pm 0.9^{\mathrm{b}}$ & $21.3 \pm 1.9^{\mathrm{c}}$ & $14.5 \pm 0.8^{\mathrm{d}}$ \\
$\mathrm{a}$ & $15.9 \pm 0.1^{\mathrm{c}}$ & $24.0 \pm 0.9^{\mathrm{a}}$ & $24.4 \pm 1.4^{\mathrm{a}}$ & $18.5 \pm 1.0^{\mathrm{b}}$ \\
$\mathrm{b}$ & $33.8 \pm 0.1^{\mathrm{a}}$ & $27.4 \pm 0.8^{\mathrm{b}}$ & $24.8 \pm 1.5^{\mathrm{b}}$ & $14.9 \pm 1.2^{\mathrm{c}}$ \\
\hline
\end{tabular}

L, brightness, a, redness; b, yellowness

$\mathrm{S}$ : Dacquoise with sugar and sugar powder

$\mathrm{T}$ : Dacquoise with tagatose and sugar powder

TS: Dacquoise with tagatose and sugar powder replacement (tagatos and starch)

TE: Dacquoise with tagatose and sugar powder replacement (tagatose, erythritol and starch).

a,b,c,d Bars with different superscripts were significantly different by Tukey's test at $p<0.05$

로 대체하여 다쿠아즈를 제조하였을 때 손실률이 더 낮았다.

\section{색도(chromaticity)}

다쿠아즈의 색도를 Table 2에 나타내었다. 쿠키의 색도는 명도 (L; lightness), 적색도(a; redness), 황색도(b; yellowness)를 3회 반복 측정하였고 평균값을 구하여 나타내었다. 명도 값은 $\mathrm{S}>$ $\mathrm{T}>\mathrm{TS}>\mathrm{TE}$ 순서였고, 적색도는 $\mathrm{TS}>\mathrm{T}>\mathrm{TE}>\mathrm{S}$ 순서였으며, 황색도는 $\mathrm{S}>\mathrm{T}>\mathrm{TS}>\mathrm{TE}$ 의 순서로 결과가 나왔다. $\mathrm{S}$ 는 명도와 황색도에서 가장 높은 값을 나타내었고, 적색도에서는 가장 낮 은 값을 나타내었다. 타가토스 첨가량이 증가할수록 적색도는 높아지는 경향을 보였고, 설탕첨가량이 증가할수록 명도와 황색 도가 증가하는 경향을 보였다.

Taylor 등(2008)은 타가토스로 제조한 쿠키가 설탕으로 제조 한 쿠키에 비하여 타가토스 량이 증가할수록 적색도는 높아지 고, 명도는 유의적으로 낮은 값을 나타내었고 보고하였다. Hwang 등(2015)도 타가토스의 첨가량이 증가할수록 명도값은 감소하고, 적색도는 증가하였다고 보고하였다. 이러한 갈변현상 은 감미료인 설탕, 타가토스, 에리스리톨이 오븐으로 열처리되 면서 Maillard반응과 caramelization으로 인해 발생된다. Maillard 반응은 당이 가지는 환원당이 아미노산을 만나면서 갈변되고 풍 미를 내는 반응이다(Maillard 1912). 2분자 화합물인 설탕은 1 개의 환원당을 가지고 있어 적당한 갈변이 일어나나, 1 분자 화 합물인 타가토스는 1 개의 환원당을 가지고 있고, 설탕에 비하 여 g당 unit의 수가 많으므로 갈변이 더 많이 일어난다. 알코올 유래당인 에리스리톨의 경우 환원당을 가지고 있지 않아 갈변 이 적게 일어난 것으로 보인다(Kim 1994). 결과적으로 타가토 스의 함량이 많아질수록 명도는 감소하고 적색도는 증가하였으 며, 에리스리톨 첨가 시 명도와 황색도가 낮아졌다.

\section{조직감(texture)}

다쿠아즈의 조직감은 Table 3에 나타내었다. 경도실험결과 $\mathrm{S}>\mathrm{TS}$ $>\mathrm{T}>\mathrm{TE}$ 순으로 높게 나타났고, 부서짐성의 경우 $\mathrm{TE}>\mathrm{S}>\mathrm{T}$ $>\mathrm{TS}$ 순으로 높게 나타났으며, 점착성의 경우 $\mathrm{TE}>\mathrm{TS}>\mathrm{T}>\mathrm{S}$ 순 으로 높은 값을 나타내었다. 탄력성과 응집성의 경우 $\mathrm{TS}>\mathrm{TE}$ $>\mathrm{S}>\mathrm{T}$ 순으로 높게 나타났는데, 에리스리톨을 첨가한 TE가 TS 보다 낮은 것으로 보아, 타가토스가 에리스리톨, 설탕에 비하여 다쿠아즈의 탄성과 응집성을 높이는 역할을 한 것으로 사료된다.

$\mathrm{TE}$ 는 $\mathrm{S}$ 와 비교 하였을 때, 경도 값이 낮고 부서짐성과 점착
Table 3 Texture analysis results of dacquoise made of alternative sweetener

\begin{tabular}{lcccc}
\hline & $\mathrm{S}$ & $\mathrm{T}$ & $\mathrm{TS}$ & $\mathrm{TE}$ \\
\hline Hardness & $712 \pm 25^{\mathrm{a}}$ & $155 \pm 20^{\mathrm{b}}$ & $183 \pm 23^{\mathrm{b}}$ & $103 \pm 24^{\mathrm{b}}$ \\
Fracturability & $2897 \pm 95.8^{\mathrm{ab}}$ & $1884 \pm 39.2^{\mathrm{b}}$ & $1869 \pm 24^{\mathrm{b}}$ & $3656 \pm 629^{\mathrm{a}}$ \\
Adhesiveness & $3.0 \pm 0.4^{\mathrm{b}}$ & $16.6 \pm 1.4^{\mathrm{b}}$ & $39.2 \pm 7.9^{\mathrm{a}}$ & $51.3 \pm 5.2^{\mathrm{a}}$ \\
Springiness & $0.45 \pm 0.02^{\mathrm{bc}}$ & $0.42 \pm 0.08^{\mathrm{c}}$ & $0.93 \pm 0.03^{\mathrm{a}}$ & $0.66 \pm 0.04^{\mathrm{b}}$ \\
Cohesiveness & $0.24 \pm 0.02^{\mathrm{c}}$ & $0.24 \pm 0.01^{\mathrm{c}}$ & $0.63 \pm 0.02^{\mathrm{a}}$ & $0.34 \pm 0.03^{\mathrm{b}}$ \\
\hline
\end{tabular}

S: Dacquoise with sugar and sugar powder

T: Dacquoise with tagatose and sugar powder

TS: Dacquoise with tagatose and sugar powder replacement (tagatos and starch)

TE: Dacquoise with tagatose and sugar powder replacement (tagatose, erythritol and starch)

${ }^{a, b, c}$ Bars with different superscripts were significantly different by Tukey's test at $p<0.05$

Table 4 Calorie and nutrients in dacquoise made of alternative sweetener (100 g daquoise)

\begin{tabular}{lcccc}
\hline & $\mathrm{S}$ & $\mathrm{T}$ & $\mathrm{TS}$ & $\mathrm{TE}$ \\
\hline Calorie (kcal) & 352 & 318.6 & 257.4 & 228.7 \\
Sucrose $(\mathrm{g})$ & 50.8 & 33.8 & 2.3 & 2.3 \\
Protein $(\mathrm{g})$ & 7.7 & 7.7 & 7.7 & 7.7 \\
Fat $(\mathrm{g})$ & 14.4 & 14.4 & 14.4 & 14.4 \\
\hline
\end{tabular}

Dacquoise with sugar and sugar powder

T: Dacquoise with tagatose and sugar powder

TS: Dacquoise with tagatose and sugar powder replacement (tagatos and starch)

TE: Dacquoise with tagatose and sugar powder replacement (tagatose, erythritol and starch)

성, 탄력성, 응집성이 높은 것으로 보아, 에리스리톨로 다쿠아 즈를 제조할 경우 부드럽지만 잘 부서지고, 점착성과 탄력성이 좋을 것으로 보인다. $\mathrm{TS}$ 는 경도에서 $\mathrm{S}$ 보다는 낮지만 $\mathrm{TE}$ 보다 는 높은 값을 보였고, 부서짐성은 $\mathrm{S}$ 와 $\mathrm{TE}$ 보다 낮았고 $\mathrm{T}$ 와 유 사한 값을 나타내었다. TS로 다쿠아즈를 제조할 경우 부드럽고 잘 부서지지 않으며 탄력성과 응집성이 좋을 것으로 사료된다. Taylor(2006)는 타가토스 $25 \%$ 로 제조한 쿠키의 경도가 설탕에 비하여 낮은 값을 나타내었고, 점착성과 탄력성, 응집성은 높은 값을 나타내었다고 보고하였는데, 본 실험의 $\mathrm{S}$ 와 $\mathrm{TS}$ 의 결과가 Taylor(2006)의 결과와 유사한 경향을 보였다. 결과적으로 타가 토스가 더 많이 함유되어 있는 $\mathrm{TS}$ 의 조직감이 가장 좋은 결과 를 나타내었다.

\section{열량(Calorie)}

열량 표시는 각 다쿠아즈의 배합 비에 존재하는 재료의 $100 \mathrm{~g}$ 당 $\mathrm{kcal}$ 를 대체감미료 별로 나타내었다. Table 4 열량의 경우 $\mathrm{S}$ $>\mathrm{T}>\mathrm{TS}>\mathrm{TE}$ 순으로 $\mathrm{S}$ 의 열량이 가장 높았고, $\mathrm{TE}$ 의 열량이 가장 낮았으며, 설탕의 경우 $\mathrm{S}>\mathrm{T}>\mathrm{TS}>\mathrm{TE}$ 의 순으로 $\mathrm{TE}$ 의 량 이 가장 낮았다. 단백질과 지방의 경우 합산 결과 모든 군이 같 은 결과를 나타내었다.

당지수는 일정한 양의 식품의 탄수화물을 섭취한 후 혈당 상 승 정도를 표준 탄수화물을 섭취 후의 혈당 상승 정도와 비교 한 값으로(Kim 등, 2012), 일반적으로 당지수가 낮은 식품은 소 장에서 흡수가 적고 간에서 포도당으로 전환되는 속도가 느려 


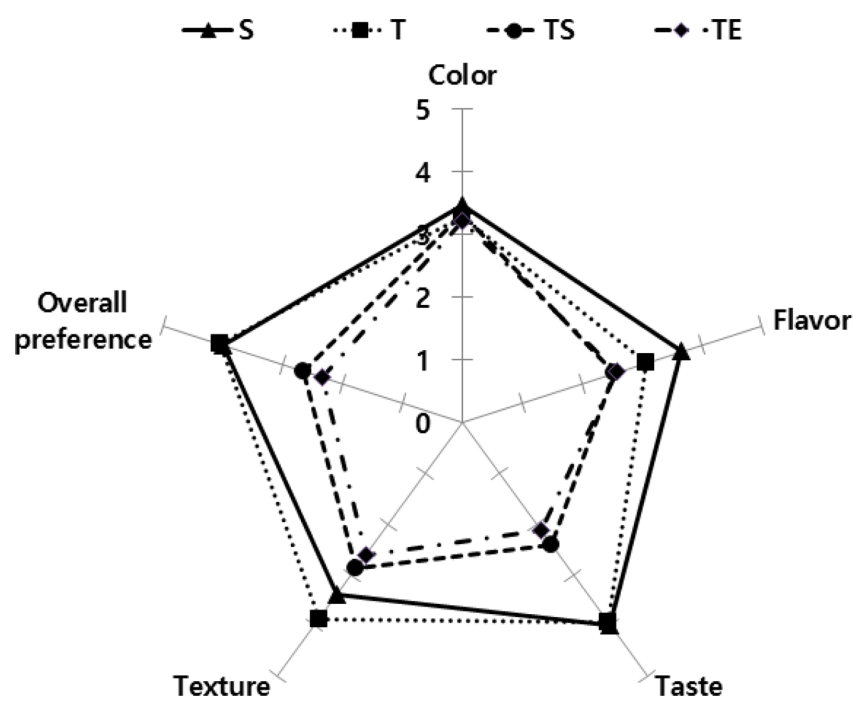

Fig. 3 Sensory evaluation of dacquoises mad of difference sweetener S: Dacquoise with sugar and sugar powder

T: Dacquoise with tagatose and sugar powder

TS: Dacquoise with tagatose and sugar powder replacement (tagatose and starch)

TE: Dacquoise with tagatose and sugar powder replacement (tagatose, erythritol and starch)

서 상대적으로 적은 인슐린을 분비시킨다( $\mathrm{Kim}$ 과 $\mathrm{Kim} 2008)$. 설탕(68), 타가토스(3), 에리스리톨(1) 순으로 높은 당지수를 나 타내므로, 에리스리톨을 함유한 $\mathrm{TE}$ 의 열량과 당지수가 가장 낮 게 나타났고, 타가토스가 함유된 $\mathrm{TS}$ 에서 낮은 열량과 당지수를 나타내었으며, $\mathrm{T}$ 는 $\mathrm{S}$ 와 비교하였을 때, 탄수화물의 함량은 큰 차이는 없었으나(T) 낮은 당지수를 나타내었다. Kang 등(2014) 은 설탕과 타가토스, 자일로즈로 제조한 초콜릿을 섭취 후 혈 당 변화에서 타가토스군이 설탕군에 비하여 유의적으로 혈당을 낮추었다고 보고하였고, 타가토스를 섭취하였을 때 열량과 당지 수가 낮다고 보고하였다. 이는 타가토스가 혈당변화에 영향을 주지 않은 것으로 보이며, 타가토스로 제조한 다쿠아즈는 열량 이 낮고 당지수도 낮으며 혈당을 크게 증가하지 않고, 과다섭 취 시 설사, 메스꺼움을 유도하는 에리스리톨에 비하여 안전하 므로, 당뇨병환자에게 적합한 간식으로 사료된다.

\section{관능평가(sensory evaluation)}

다쿠아즈의 관능평가는 호서대학교 학생 중 자원자 15 명을 선 발하고 이들에게 관능평가 방법을 교육시킨 후 제조한 다쿠아 즈를 평가하도록 하였다. 다쿠아즈의 평가항목 인 색(color), 향 (flavor), 맛(taste), 질감(texture), 전체적 기호도(overall acceptance) 의 5 가지의 항목에 대하여 설명하고, 1 에서 5 점까지의 척도를 사용한 채점 척도 시험법을 사용하여 평가하였다. 평가자들에게 물을 제공하여 다쿠아즈 시식 전, 시식 후 입안을 헹구고 평가 하도록 지도하였다.

관능평가의 결과는 Fig. 3에 나타내었다. 전체적 기호도는 $\mathrm{S}$ $>\mathrm{T}>\mathrm{TS}>\mathrm{TE}$ 로 $\mathrm{S}$ 와 $\mathrm{T}$ 그리고 $\mathrm{TS}, \mathrm{TE}$ 간에 유사한 경향을 보 였다. 색상평가 결과 $\mathrm{S}$ 가 높았고 $\mathrm{TE}$ 가 가장 낮았지만, 군들간 의 차이는 0.2 로 미미한 차이를 보였다. 향미의 평가 결과 $\mathrm{S}$ 가
가장 높았고, $\mathrm{TS}$ 가 가장 낮았다. 다쿠아즈를 굽는 과정에서 설 탕이 향미가 타가토스나 에리스리톨에 비하여 좋은 풍미를 나 타내어 위와 같은 결과가 나온 것으로 사료된다. 맛 평가의 경 우 $\mathrm{S}$ 가 가장 높았지만, $\mathrm{T}$ 와의 차이가 약 0.07 점인 것으로 보아 설탕으로 제조한 다쿠아즈와 타가토스로 제조한 다쿠아즈 간의 맛 차이가 거의 없는 것으로 확인되었다. TS는 분당 대신 타가 토스가 들어가있고, 결과적으로 T보다 더 많은 양의 타가토스 가 들어가 있다. 설탕은 타가토스보다 더 단맛을 내므로 $\mathrm{TS}$ 가 $\mathrm{T}$ 보다 맛에 대한 평가가 낮은 것으로 사료되며, $\mathrm{TE}$ 의 경우 평 가가 가장 낮았는데, 에리스리톨의 특성상 단맛은 입 속에 남 지 않고 상쾌한 맛을 나타내므로 점수가 낮은 것으로 보인다. 또한 조직감의 경우 $\mathrm{T}$ 가 가장 높았으며, $\mathrm{TE}$ 가 가장 낮았다. $\mathrm{TE}$ 의 경우 에리스리톨은 결정성이 우수하고 흡습되기 어려운 성 질을 가지기 때문에(Oh와 Choi 2002) 수분량이 줄어들어 조직 이 경화되어 단단하므로 조직감에서 낮은 평가를 받은 것으로 사료된다.

전체적인 결과로는 $\mathrm{TE}$ 는 향미를 제외한 각 항목마다 가장 낮 은 수치를 보였으며, $\mathrm{S}$ 와 $\mathrm{T}$ 는 향미와 조직감을 제외한 모든 관 능평가에서 유사한 높은 점수를 받았다. TS는 각 항목에서 향 미를 제외하고 $\mathrm{TE}$ 보다 높은 점수를 받았다. 에리스리톨로 제조 한 다쿠아즈에 비하여 타가토스로 제조한 다쿠아즈가 색, 향, 맛, 질감 및 전체적 기호도 평가에서 높은 값을 나타내는 것으 로 보아 타가토스가 다쿠아즈 제조에 적합한 대체감미료로 사 료되며, $\mathrm{T}$ 는 $\mathrm{S}$ 와 비교하였을 때 관능평가에서는 유사한 평가를 받았으나, 대체 감미료가 차지하는 비율이 약 $33.3 \%$ 이므로, 대 체 감미료 비율이 $95.1 \%$ 로 높았던 TS로 제조된 다쿠아즈가 당뇨병 환자나 대사성 증후군을 겪고 있는 환자에게 적합한 것 으로 사료된다.

\section{초 록}

우리나라의 경우 서구화된 식생활과 식습관으로 인하여 케이크 류, 비스킷류 등의 다양한 서양식 제과를 접하게 되었다. 하지 만 제과의 특성상 주재료인 설탕을 넣어 제조하고 열량과 당지 수가 높아져 당뇨병환자들에게는 제한 될 수 밖에 없다. 그래 서 본 연구에서는 설탕을 타가토스와 에리스리톨로 대체한 다 쿠아즈를 제조하여, 물리화학적인 특성과 관능평가를 통하여 열 량과 당지수가 높은 제과의 단점을 보완하고자 하였다.

실험 결과 비중의 경우 $\mathrm{TE}$ 가 가장 높은 값을 나타내었으나 군들간에 유의적인 차이를 보이지 않았으므로, 다쿠아즈 제조 시 부피(품질)에 영향을 미치지 않은 것으로 보였다. 퍼짐성에 서는 비중의 결과와 유사하였고, 손실률에서는 $\mathrm{S}$ 가 가장 높은 값을 나타내었는데, 설탕의 함량이 높을수록 높은 손실률을 나 타내었다. 색도의 경우 명도와 황색도 값은 $\mathrm{S}$ 가 가장 높았고, 적색도 값은 타가토스가 첨가 되었던 $\mathrm{TS}$ 와 $\mathrm{T}$ 가 높았다. 당도 의 경우 $\mathrm{S}$ 가 가장 높았고 $\mathrm{TE}$ 가 가장 낮았으며, $\mathrm{T}$ 는 $\mathrm{S}$ 와 $\mathrm{TE}$ 사이 값을 나타내었고, 열량에서는 당도 결과와 유사한 양상을 보였다. 마지막으로 관능평가에서 $\mathrm{T}$ 가 향미와 조직감을 제외한 모든 평가에서 $\mathrm{S}$ 와 유사한 결과를 나타내었으며, $\mathrm{TE}$ 가 가장 낮 은 평가를 받은 것으로 나타났다.

대체감미료를 사용하여 제조한 다쿠아즈의 물리적 특성 실험 
결과, 에리스리톨 함유 다쿠아즈(TE)는 손실률과 열량에서 가장 좋은 결과 값을 나타내었으나 관능평가에서 전체적으로 낮은 평 가를 받았고, $38.3 \%$ 타가토스를 함유 다쿠아즈(TS)는 손실률과 열량이 낮고, 관능평가에서 $\mathrm{TE}$ 보다 높은 점수를 받았다. $13.4 \%$ 타가토스로 제조한 다쿠아즈(T)는 설탕으로 제조한 다쿠아즈(S) 와 물리적 특성 실험결과와 관능평가 결과가 유사했는데, 이는 유사한 설탕함량으로 인한 결과로 사료된다. 본 연구에서는 혈 당 변화 실험은 하지 않았지만, 선행 연구에서 타가토스를 사 용하여 초콜릿을 제조 하였을 때, 설탕을 사용한 대조군에 비 해 유의적으로 혈당 상승을 억제시키는 효과가 있었으므로, 다 쿠아즈도 같은 경향을 나타낼 것으로 사료된다. 다쿠아즈는 탄 수화물에서 밀가루의 비중이 적고 설탕이 대부분이므로, 설탕을 타가토스로 대체하여 제조한 다쿠아즈(TS)는 당뇨병환자의 간 식으로 제공될 수 있다. 또한 혈당 상승 억제 효과가 뛰어나고 당지수가 낮은 타가토스로 제조한 다쿠아즈를 제품화할 경우, 당뇨병환자뿐만 아니라 비만이거나 혈당조절이 필요한 환자의 간식으로 적절하므로, 혈당 조절과 체중증가 억제 효과가 있는 다쿠아즈를 섭취할 수 있는 기회를 제공할 것으로 사료된다.

Keywords 다쿠아즈-대체감미료·설탕-에리스리톨-타가토스

감사의 글 이 논문은 2016년도 정부(미래창조과학부)의 재원으로 한국연구 재단-전통문화융합연구사업의 지원을 받아 수행된 연구임(No. NRF2016M3C1B5907152).

\section{References}

AACC (1983) Approved Methods of the AACC. (8th ed.), American Association of Cereal Chemists international, Saint Paul

AACC (1985) Approved Methods-9th ed. Method 10-50D. American Association of Cereal Chemists international, Saint Paul

Akesowan A (2009) Quality of reduced-fat chiffon cakes prepared with erythritol-sucralose as replacement for sugar. Pakistan J Nutr 8: 1383 1386

Child J, Simone B (1978) Mastering the Art of French Cooking. Harmondsworth: Penguin Books, London

Chiu CJ, Liu S, Willett WC, Wolever TM, Brand-Miller JC, Barclay AW, Taylor A (2011) Informing food choices and health outcomes by use of the dietary glycemic index. Nutr Rev 69: 231-242

Chung HK, Park SS (1995) The effect of sugar intake on attention deficit hyperactivity Disorder of school children. Kor J Nutri 28: 644-652

Donner T, Wilber JF, Ostrowski D (1996) D-tagatose: A novel therapeutic adjunct for non-insulin dependent diabetes. Diabetes 45: 125a

Fujimaru T, Park JH, Lim J (2012) Sensory characteristics and relative sweetness of tagatose and other sweeteners. J Food Sci 77: 323-328

Hwang JY, Kim YJ, Lee SM (2015) Studies on the physical characteristics of muffins with tagatose and sugar during storage. J East Asian Soc Dietary Life 25: 176-182

Hwang YK, Lee HT, An HL (2014) Quality characteristics of muffins with tagatose. J East Asian Soc Dietary Life 24: 802-810
Kang SA, Lee JS, Jeong AR, Kim EH, Park SM (2014) The effects of using artificial sweeteners and coffee grounds in chocolate filling on quality characteristics and glycemic index. J Appl Biol Chem 57: 307-312

Kang YS, Lee WY (2016) Mass distribution of sugar made from GM microorganisms. Korea Food \& Drug Administration, Cheongju

Kim DH (1994) Food chemistry. Tamgudang, Seoul

Kim HR, Kim SW, Sou JS, Jung HK, Kang JM, Juon SK (2015) Policy report: Establishment of the common food guide. Ministry of health \&Wellfare, Korea Institute for Health and Social Affairs, Sejong

Kim HY, Jo MS, Jang YA, Won HS, Lee HS, Lee HS, Yang EJ (2012) Clinical nutrition. ShinKwang Publishing Co., Seoul

Kim HK, Lee GH (2016) Characteristics of sponge cake prepared with yacon concentrates as sugar substitute. J Korean Soc Food Sci Nutr 45: 14531459

Kim JH, Kim SG (2008) Glycemic index and diet. J Health Prom 4: 15-22

Lakshminarayan SM, Rathinam V, KrishnaRau L (2006) Effect of maltodextrin and emulsifiers on the viscosity of cake batter and on the quality of cakes. J Sci Food Agric 86: 706-712

Lee EA, Woo KJ (2001) Quality characteristics of Jeung-Pyun (Korean rice cake) according to the type and amount of the oligosaccharide added. Kor J Soc Food Cookery Sci 17: 431-440

Lee JY, Song JH (2016) Cause of death in 2015. Statistics Korea, Daejeon

Lee SJ, Paik JE, Han MR (2008) Effect of xylitol on bread properties. Kor J Food Nutr 21: 56-63

Levin GV (2002) Tagatose, the new GRAS sweetener and health product. J Med Food 5: 23-36

Ludwig DS, Peterson KE, Gortmaker SL (2001) Relation between consumption of sugar-sweetened drinks and childhood obesity: a prospective, observational analysis. Lancet 357: 505-508

Maillard LC (1912) Formation of melanoidins in a methodical way. Compt Rend 154: 66

Noda K, Nakayama K, Oku T (1994) Serum glucose and insulin levels and erythritol balance after oral administration of erythritol in healthy subjects. Euro J Clin Nutr 48: 286-292

Oh SH, Choi HS (2002) Sweetener handbook, Hyoil Publishing Co., Seoul

Pareyt B, Talhaoui F, Kerckhofs G, Brijs K, Goesaert H, Wevers M, Delcour JA (2009) The role of sugar and fat in sugar-snap cookies: Structural and textural properties. J Food Engineer 90: 400-408

Pasha I, Butt S, Anjum FM, Shehzadi N (2002) Effect of dietetic sweeteners on the quality of cookies. Analysis 8: 20

Roh HJ, Kim SY, Kim SS, Oh DK, Han KY, Noh BS (1999) Physicochemical properties of a low calorie sweetener, tagatose. Kor J Food Sci Technol 31: 24-29

Ronda F, Gómez M, Blanco CA, Caballero PA (2005) Effects of polyols and nondigestible oligosaccharides on the quality of sugar-free sponge cakes. Food Chem 90: 549-555

Son SM, Lim HS, Kim JH, Lee JH, Suh JS, Son JM (2011) Clinical nutrition, Gyomoon Publishers, Paju

Storey D, LEE A, Bornet F, Brouns F (2007) Gastrointestinal tolerance of erythritol and xylitol ingested in a liquid. Eur J Clin Nutr 61: 349-354

Taylor T (2006) Evaluation of the bulk sweetener D-tagatose and the high intensity sweetener Splenda as sugar replacers in cookies. Dissertation, Auburn University

Taylor TP, Fasina O, Bell LN (2008) Physical properties and consumer liking of cookies prepared by replacing sucrose with tagatose. J Food Sci 73: $145-151$ 